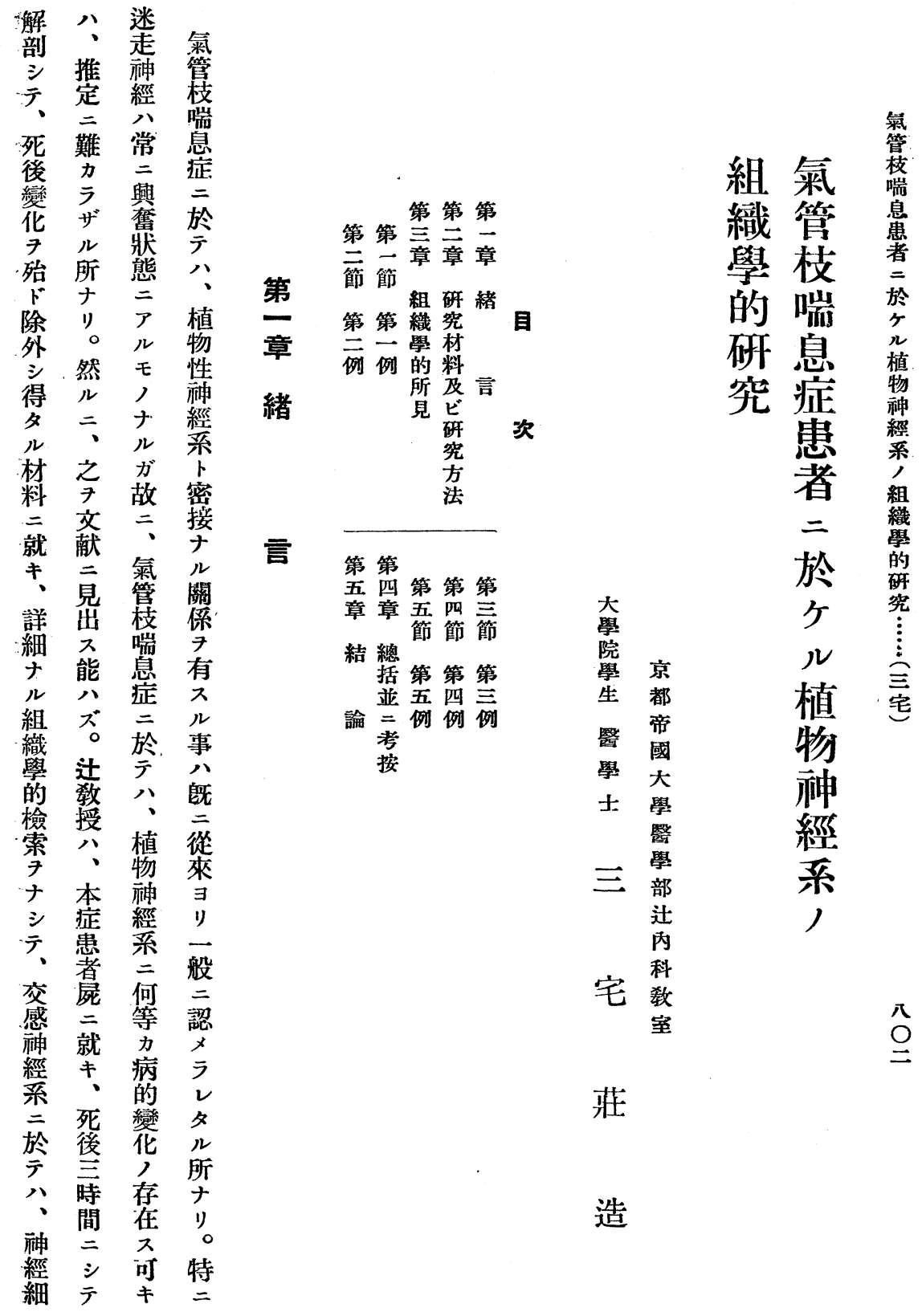



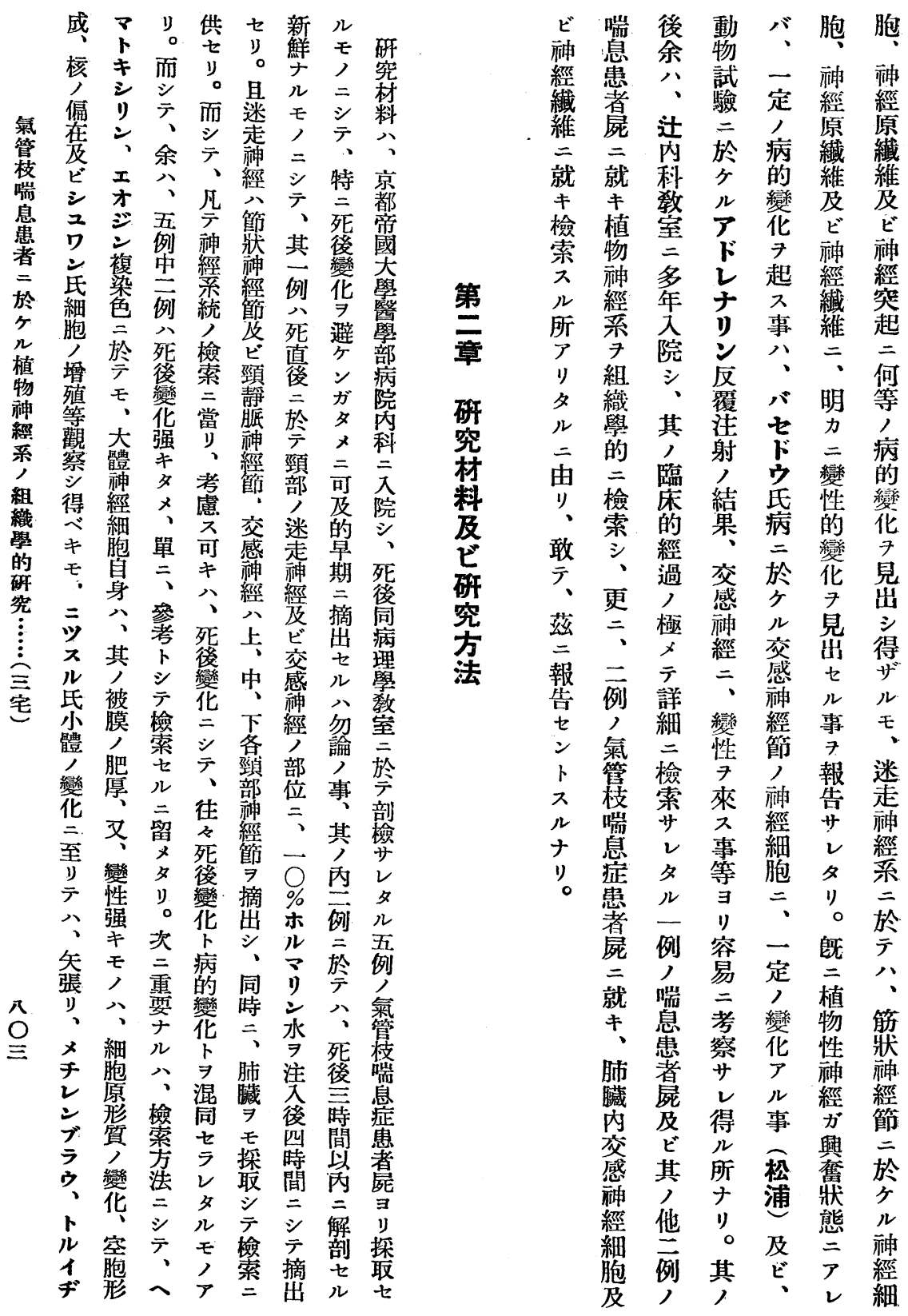
索變、述余染索、ルトキルス胂練經ス法八ン

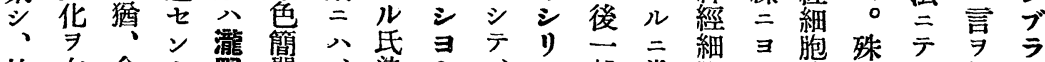

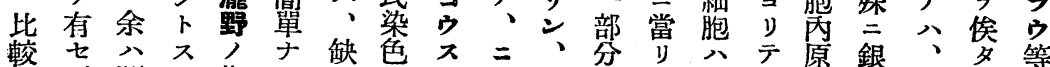

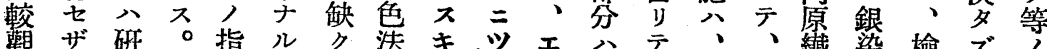

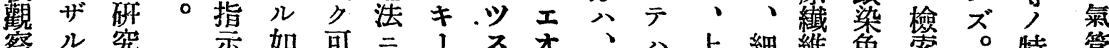

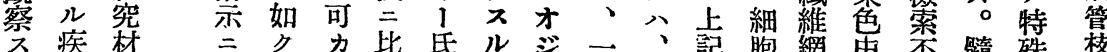
ル患料 從見

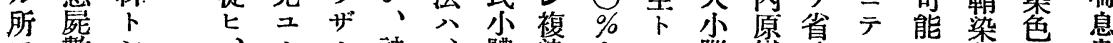

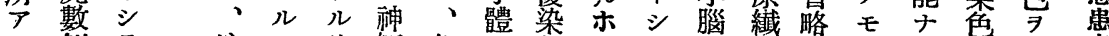

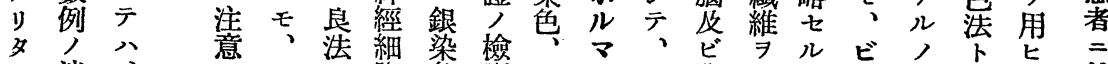

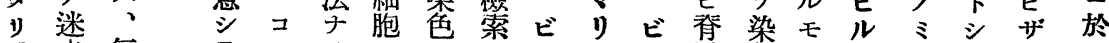

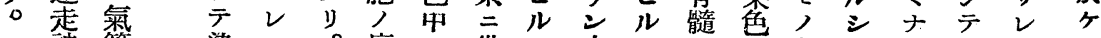

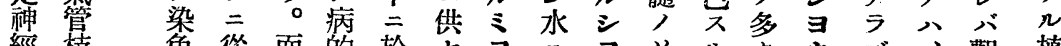
經枝色從而的於七妇当りル多ウ ズ、觀植

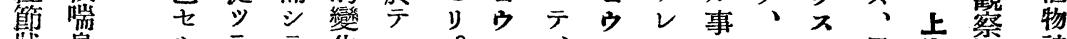

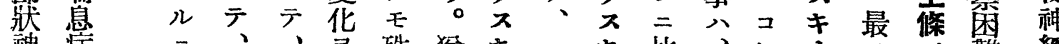

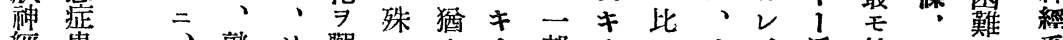

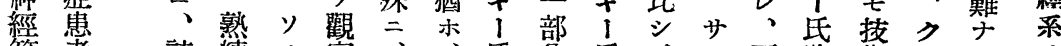

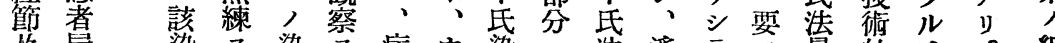
及豦染

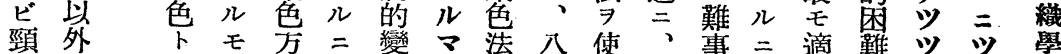

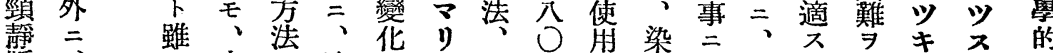

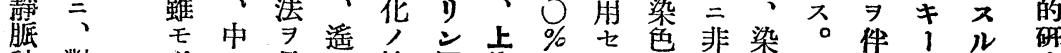
神對必々見カ檢固條アリ困ザ色從フ氏氏究

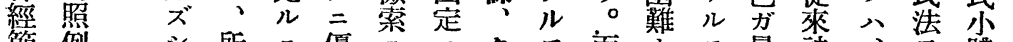

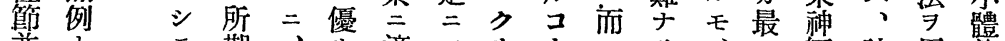
並

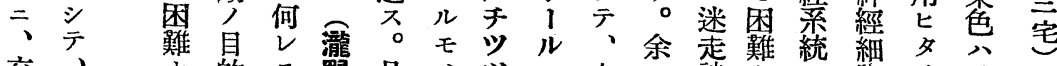

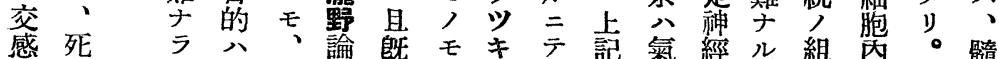

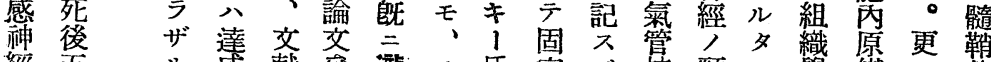

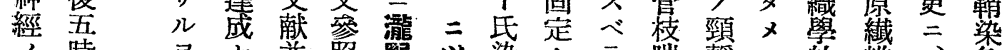

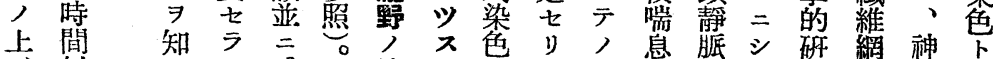
、

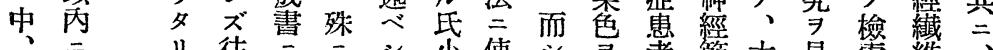

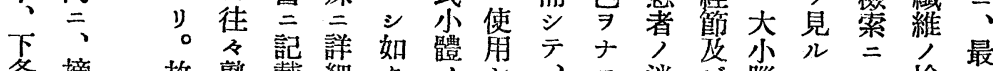

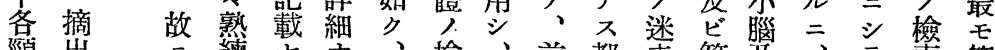

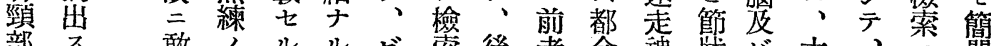

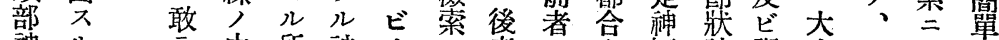
神 ル中所神ル分者三卡經神脊小少 經事次途分經シ可三方筮經髓腦レ上ル

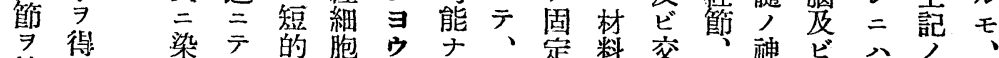
摘夕色放二八ス儿固七八感並經脊銀如脫

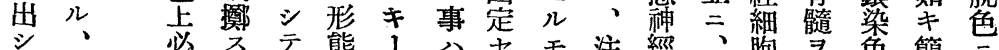

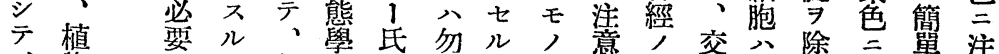

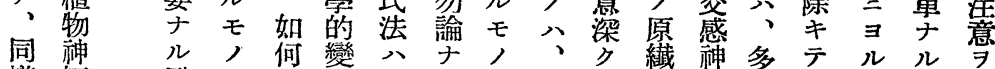

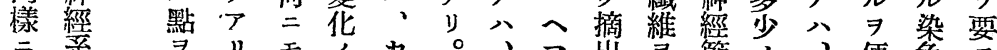

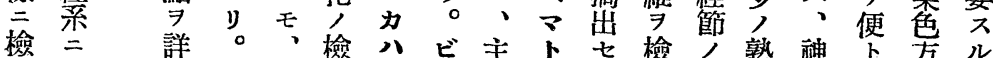




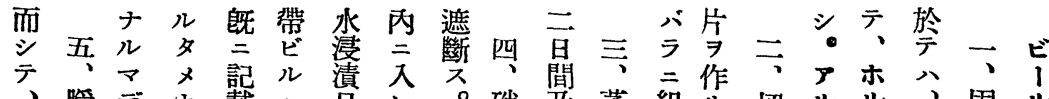

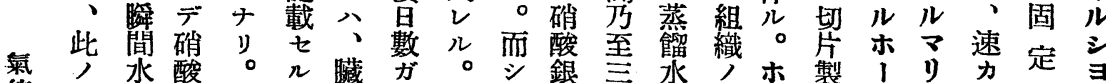

管際洗銀然如器最切テ水百三破儿作儿泣三法ウ

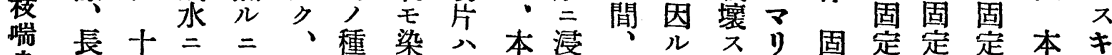

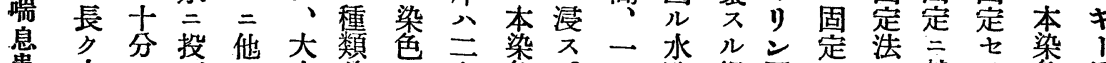

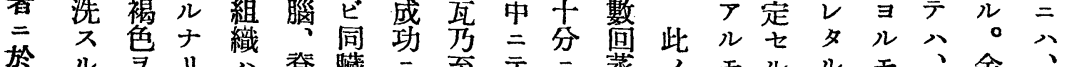

於

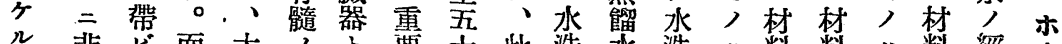

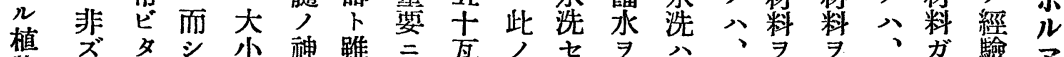

物

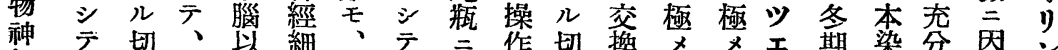

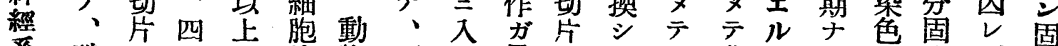

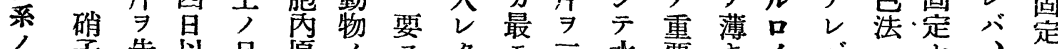

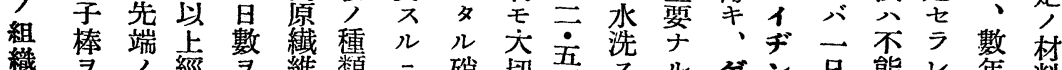

織 $\ni$ 經婎維類二硝切吾几ルぶン日能々年料

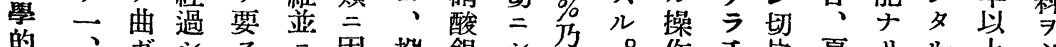

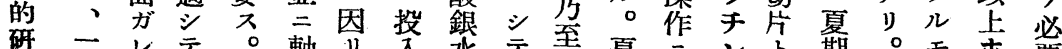

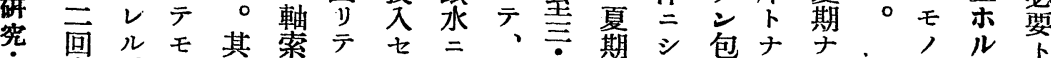

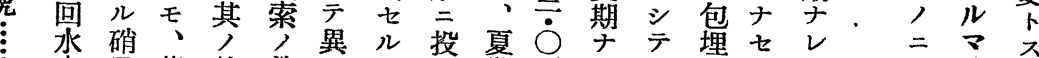

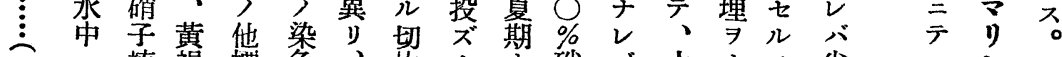

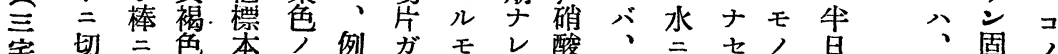

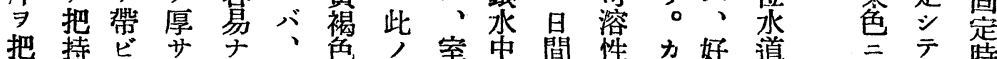

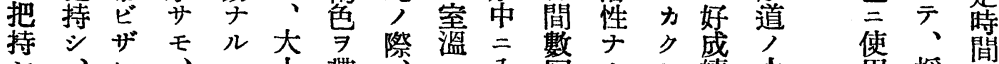

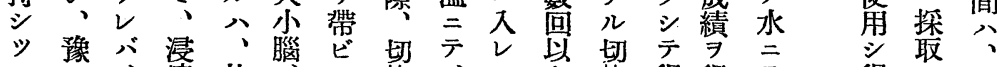

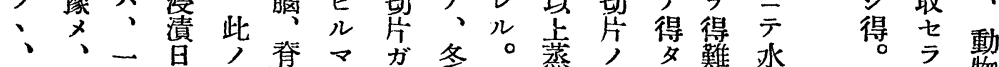

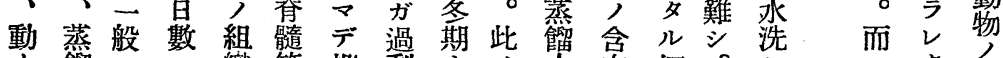

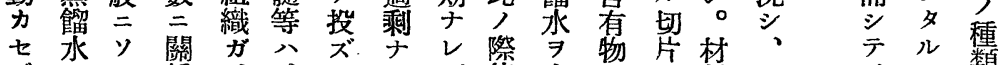

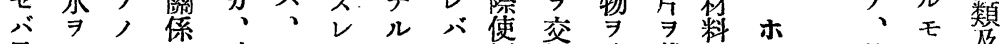

足入切了硝一心゙八、角換洗蒸 $=$ ル此, 芯

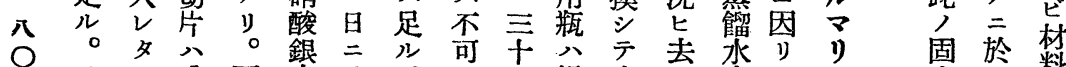

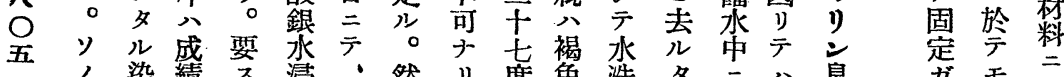

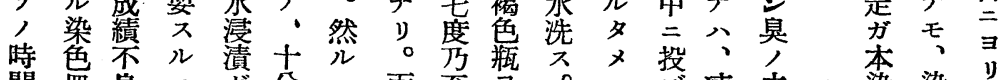

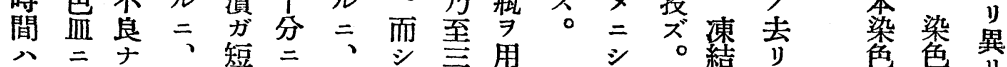

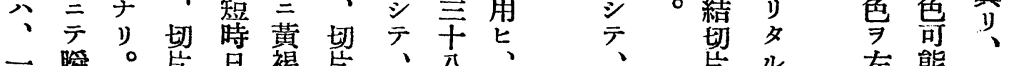

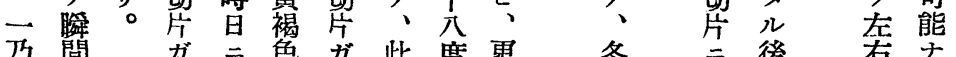

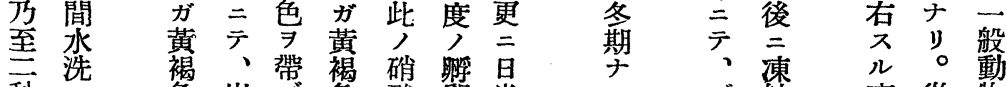

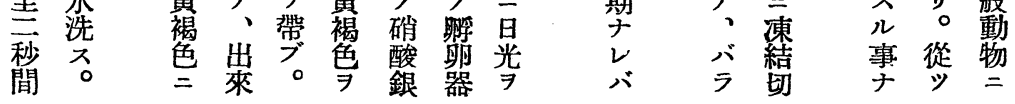




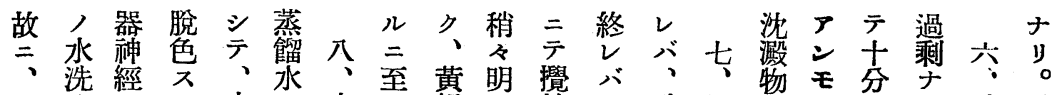

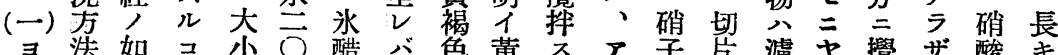

リ最 $\neq$ 卜 腦 c.c. 酸不色褐 。

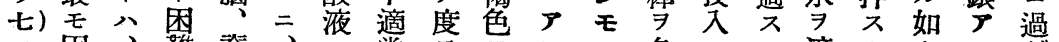

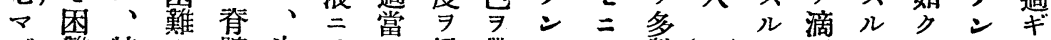

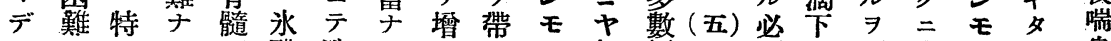

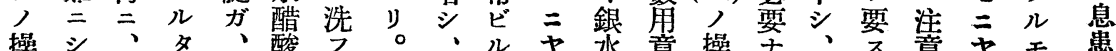

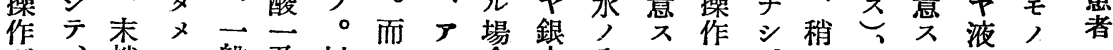

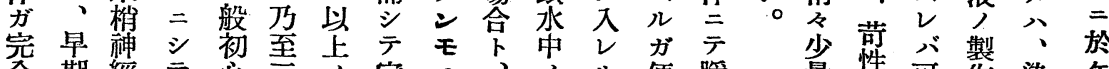

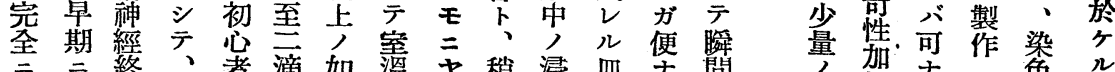

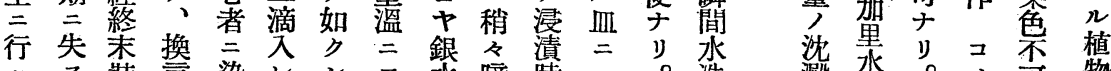

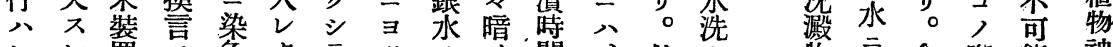

レ $レ$ 䈯

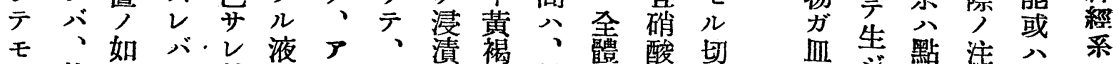

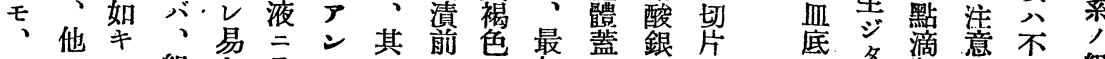

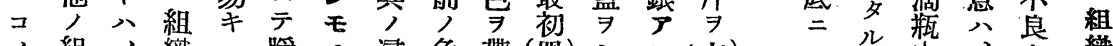

筯: 織八瞬二漫色帶 (四) シ

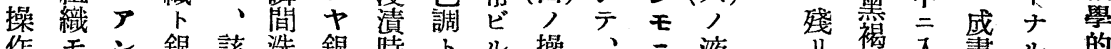

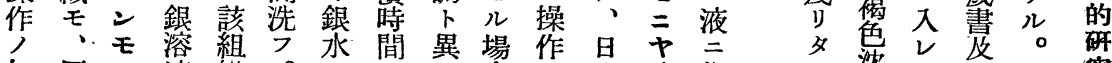

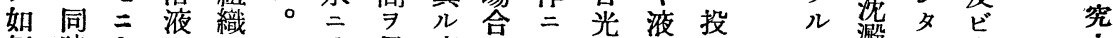

何時ヤ銀,

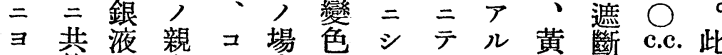

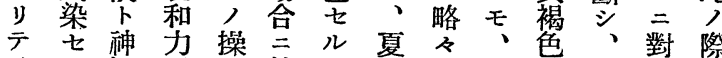

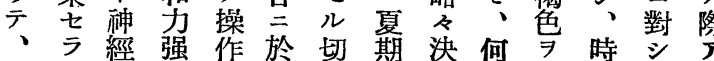

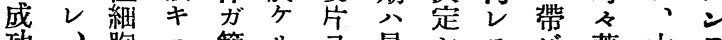

功稍脽

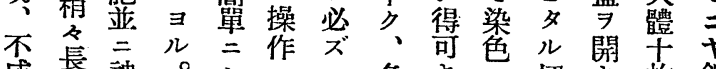

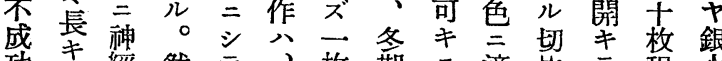

功

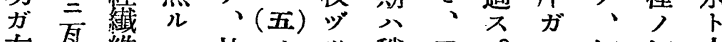

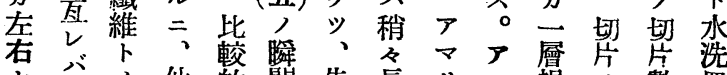

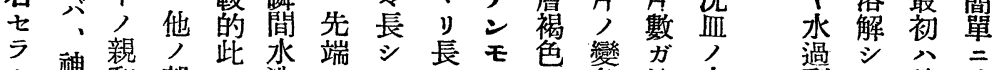

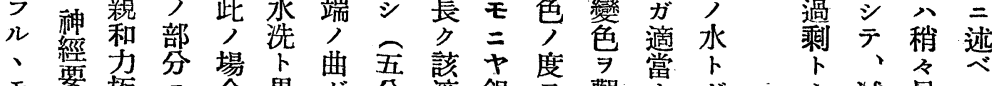

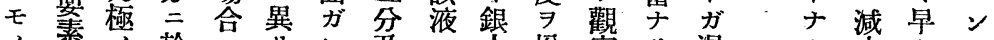

ナ合

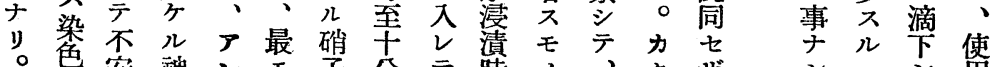

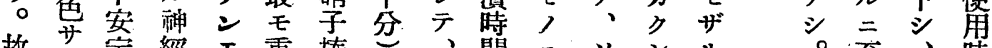

故レ定經モ重棒

シザナ 細 キ要

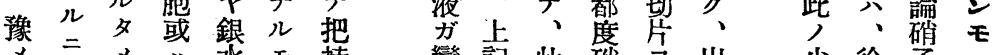

、至 、分承モ持變記此硝 $尹$ 出少徐子

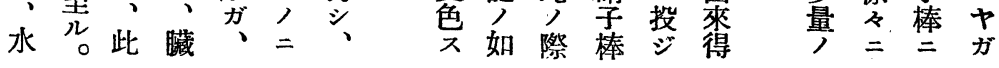




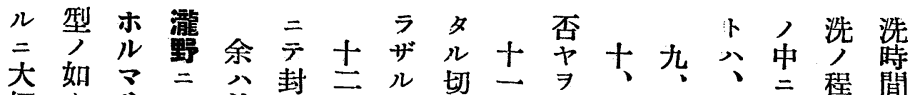

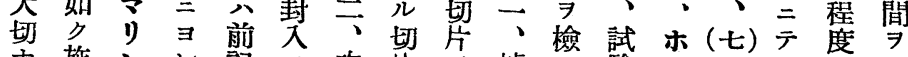

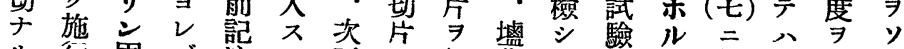

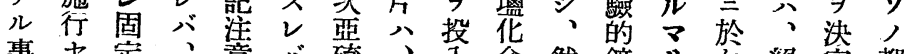

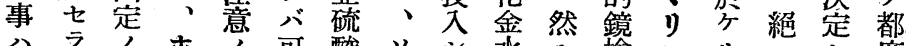

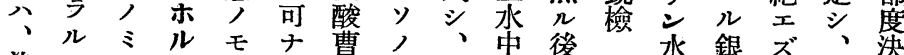

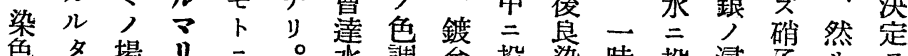

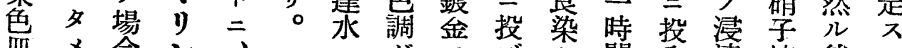

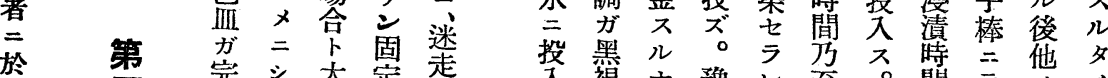
於 第 耑 シ 大定 走

植

物

神

䌦

系

組

組 洗 意卡ル 䕥

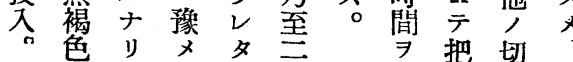

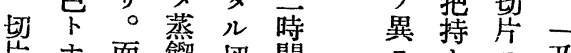

片ナ而箬切間 三

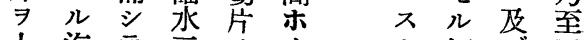

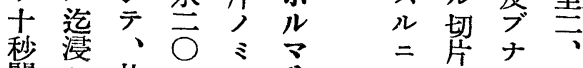

間 $シ$ 此 c.c. $尹$ 甲

万存中撰文水。枚

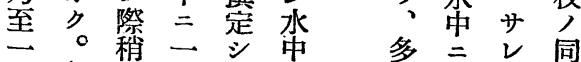

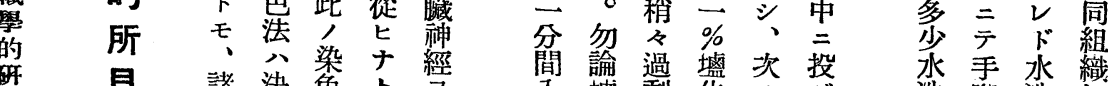

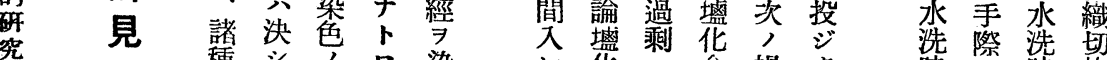

引

種テ困口染

液困䨅ラ色

$\checkmark$ 化 = 金操 夕

ル金染水作 ル

二溶色而立留

時 $\exists$ 時 片

活㬮ナ宁ル

染染、或極

レ色 (四) 諸 テ

ザ韭(五)家良

事ザ ル (六) 報 績

シナ、セ得

テ、 、(七) 出

殊唒(八) 如 》

二（四）等 ピ ソ

公

(七)五) 操卢成

場 (六) 作さ績

合 (六) 只 命

八操 單 前少

此作成茞蹎

注、畫真本

意染是 シ 示

奇色記モ不

ナ 左 シ 概 如

リ右 如齐

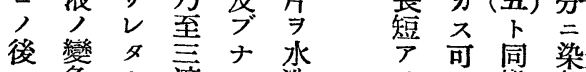

永色儿滴》。洗

浩 ル

間 ク 間 $\Rightarrow$

憅 (五) 稌

リ。。羕色

唒 、元

）此極 事

水 云萑 $\overrightarrow{\text { ग 豫 }}$

$\Rightarrow$ 上等

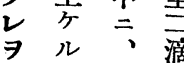

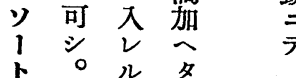

場 要要

合 僢 ナ

最間少。

三 而

水 テ 咅

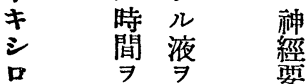

洗約

1 短 作

ル 学

入 クテ、染

要

ル

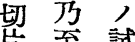

全 驗

最秒角

後間 切

氷り 片

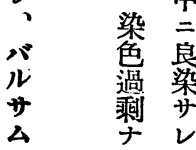

洗。

儿水 僢

㐂 洗 䦭 


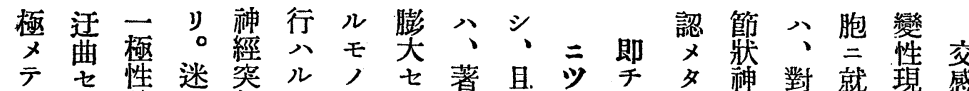

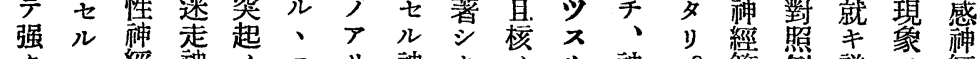

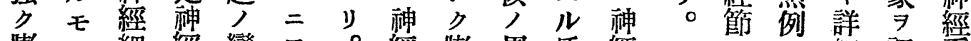
膨, 細 經變 $\exists$ 經膨周氏經 $=$ 細認第 隆了胞節花り县突隆園小細比 ス。 膨而テ經シ層變橫 或テ關腫

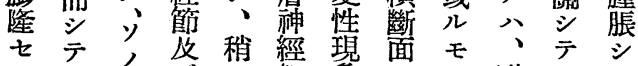

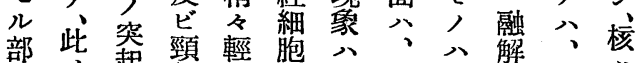

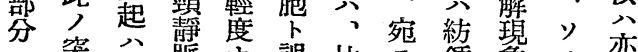

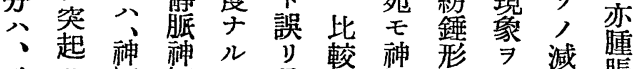

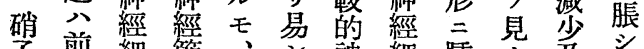

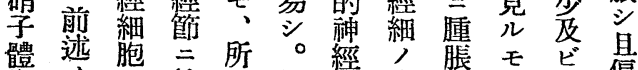

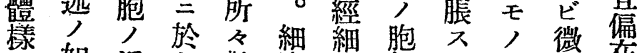

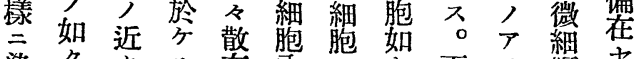

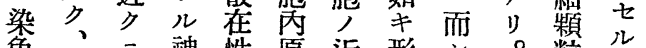

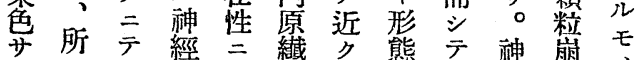

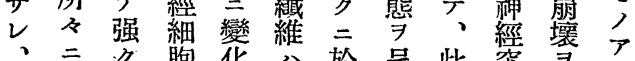

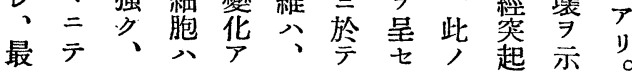

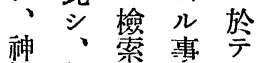

經組 永学

細織 ル 得、息

胞學所 $ス$ 神者

及 的 $>\circ$ 經 ビ 變り效 細 神华夕 等 經 $\Rightarrow$ 余发 瀻 認モ 公 ビ 維 メ゙ 肺 肺 瀻 、。臟 臟 維 明迷 內 苁 變 走 撼 於 等 性經 感 於等 的 㘘經 几 變 變 於細神华 华宁胞經 特

第於

節植

管 神

第 䌐

例系

小 縕

O 學

氏 的

取テセ起示。

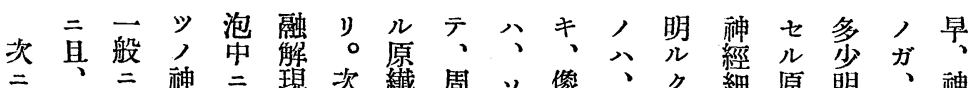

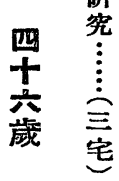
态

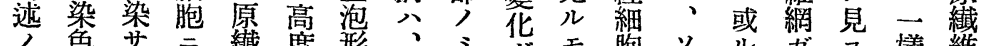

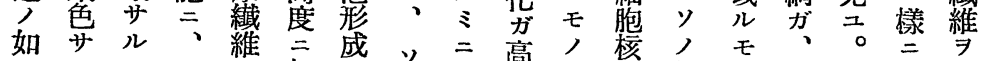

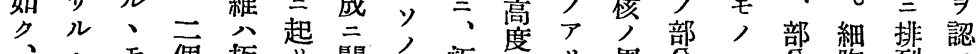

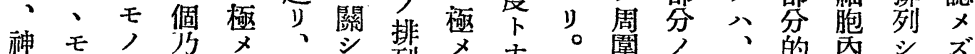

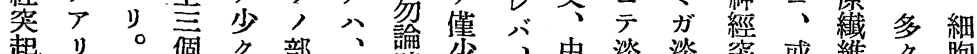

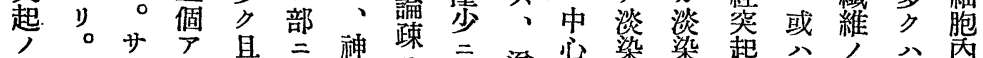

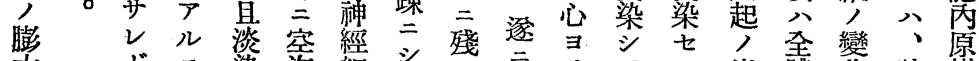

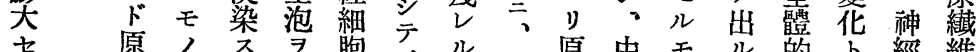
セ原ノス $、$ 胞テ、ル原中 モ的ト經維

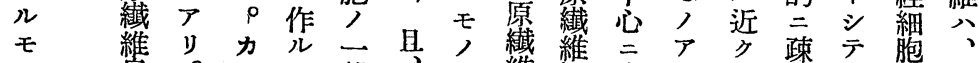

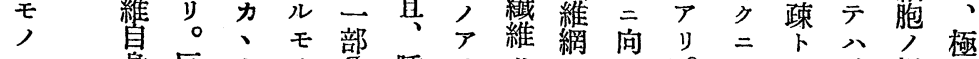

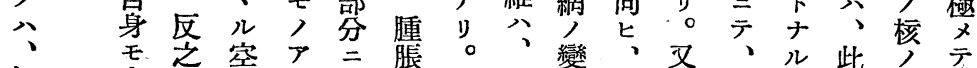

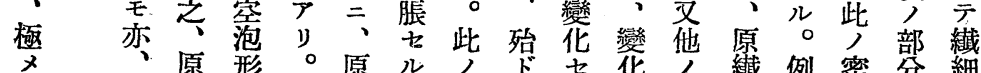
テ 多瀻晟コ

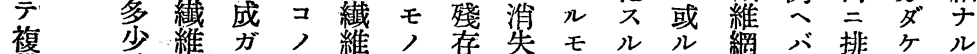
雜 疎 ガ 


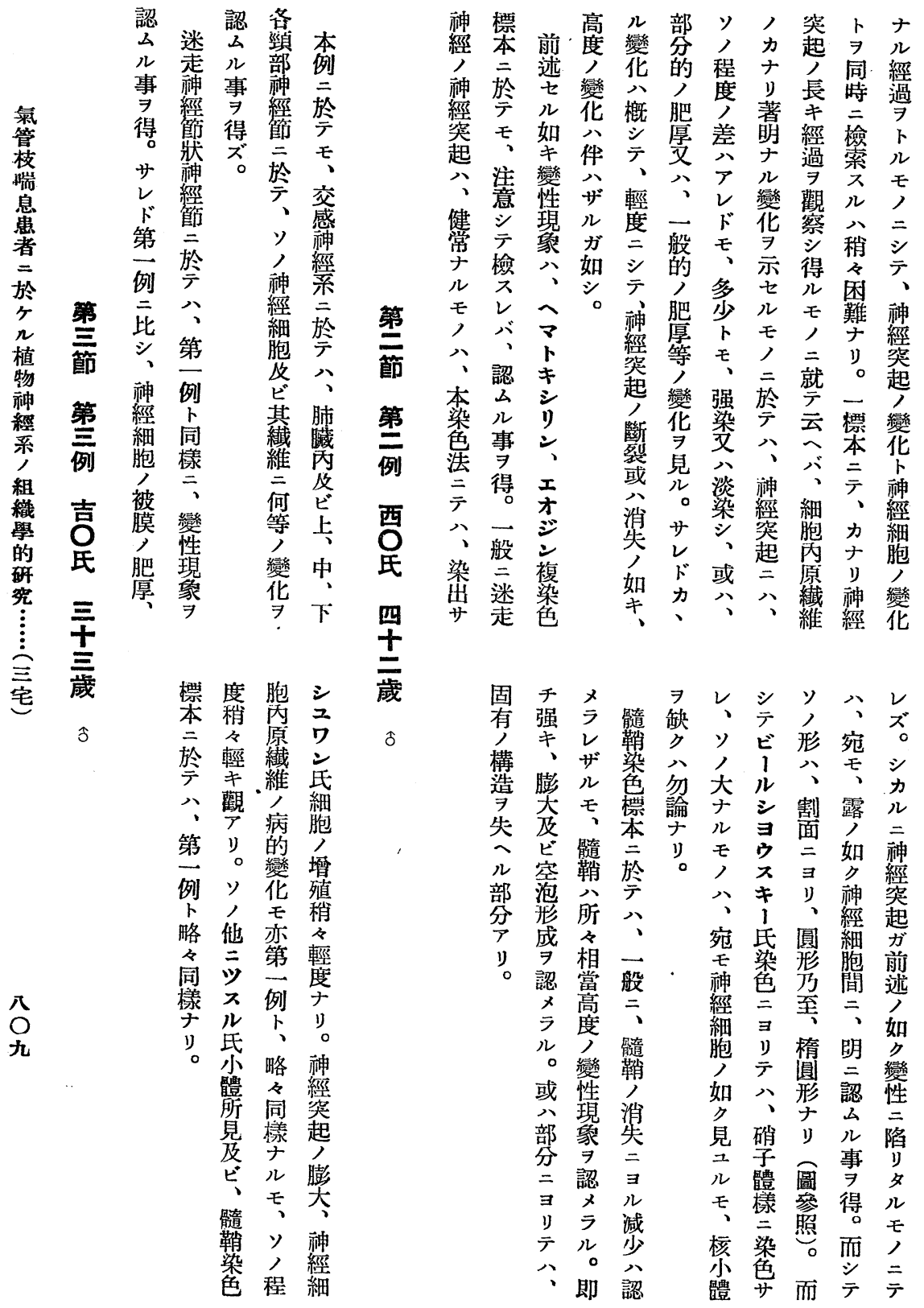


静 維 各

脈 維复

神於部上

經 テ 神ノ

節 八 經 所

$\ni$ 、節 見

摘 組及

出 織 ビ 總

七學 肺 括

ザ 的 贜 亚

1) 內 二

何, 考

夕等 交按

× 感

二變神ン

、化經

之 細

7 認胞 氣

檢 $x$ 或 管

ス ズ 枝

能艾喘

能 具感 息

方他种 症

ザノ經 患

シ例維 屍

モ立組五

死 テ 織 中

後心學

相、的三

當頸二例

部八二

時 紊 無 於

間 感 髓 テ

7 种神

經 經 經 交

七及維 感

ルビし神

材迷又經

料走八系

$ナ$ 神 菲 二

り經 薄 於

シ 節ナテ

係爿少、

亏 經 有上

ス 箁 骼

肺ビ 經

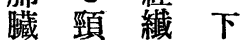

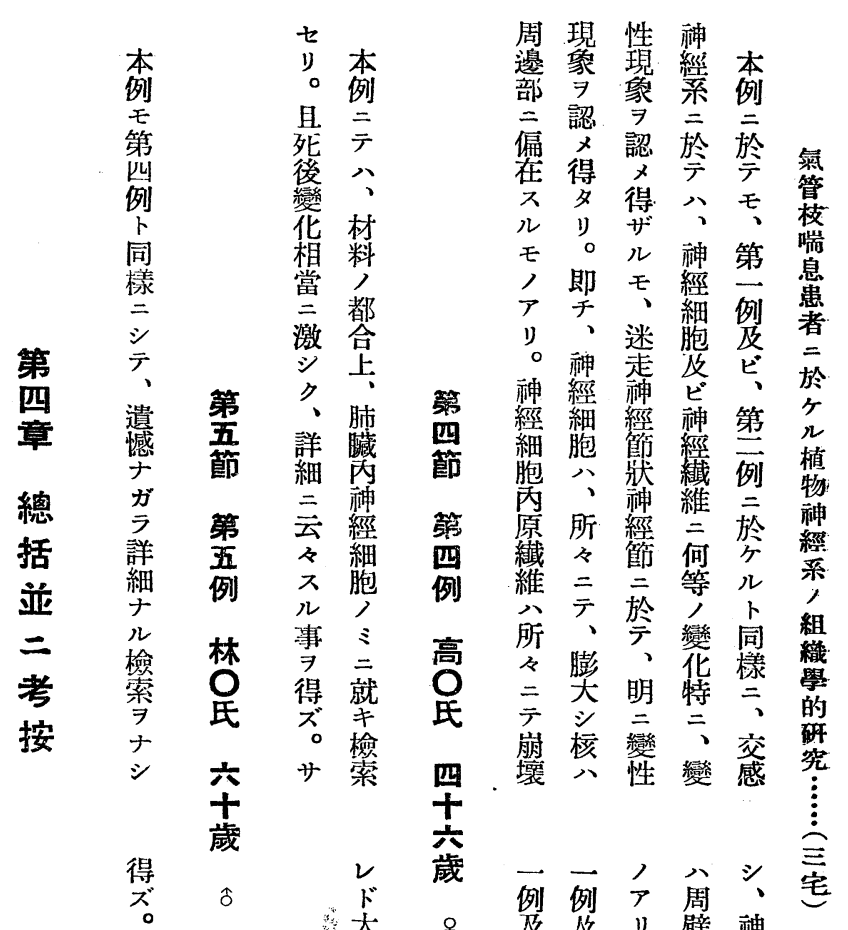

單

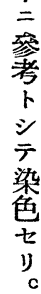

范 ピ。壁 神

第第 立 偏突

注ル軸或

リ略氏索 ル

輕々小的

度同體、,

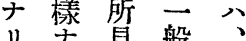

見般

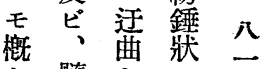

テ旤䩪、著

全染中棌

テ急 檩 膨

變 本宾

性云海 旗

爱宁成、

壬 $九$ 原戴

第 第 モ 維 
物 : 細分的 シ シ 脈經 云第全然變”。

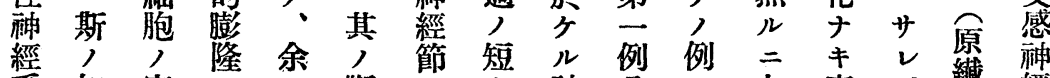

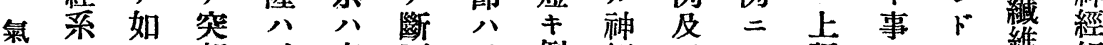
管二キ起、交面、例經 ビテ記 ヨコ維細

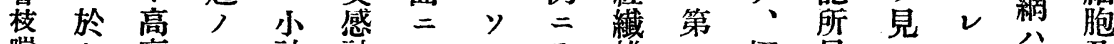

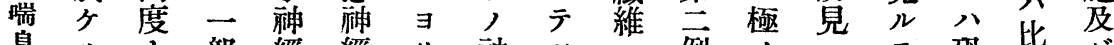
息ルナ 部 經 經り神八例 メこモ恐毕 ビ 患變儿分細細 $テ$ 經 輕突二テ反明今較無

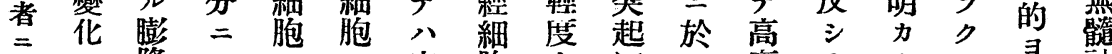

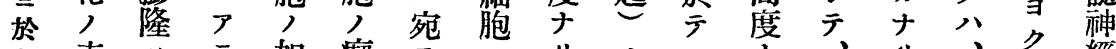
圭分 ラ 如 瀨 モ 植 處 $レ$ 外彎神極此化神 ザ走後後維 物 ル二居 觀 性 經 性, 7 經 ル神

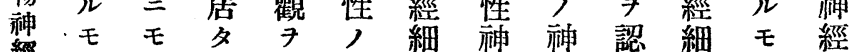

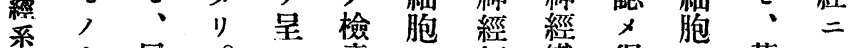
租儿擊少, 如胞維被琞,

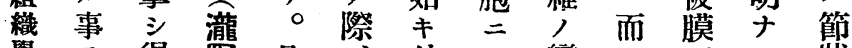

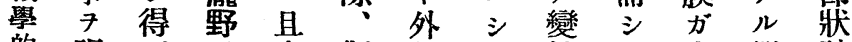

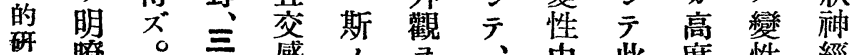

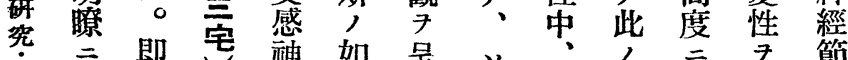

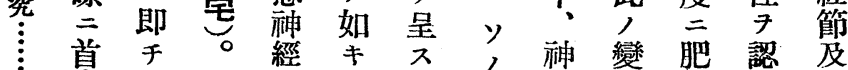

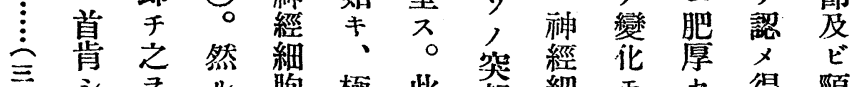

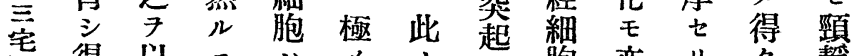

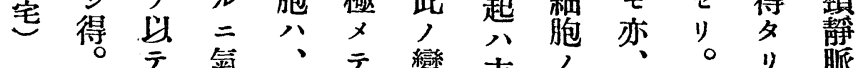

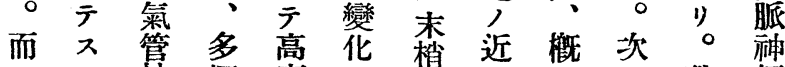

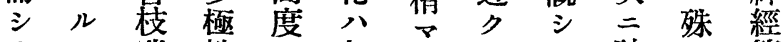

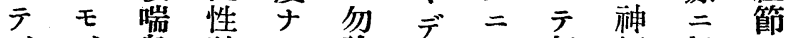

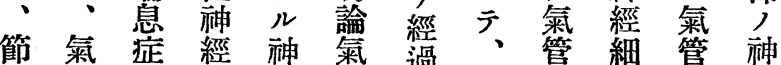

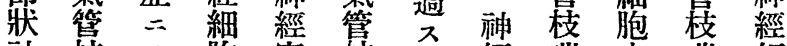

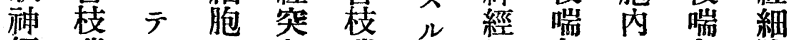
經喘八子起喘无細息原息胞

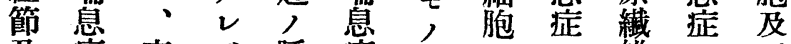

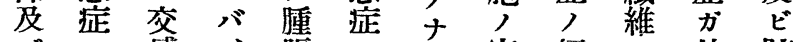

几 飞感: 脤

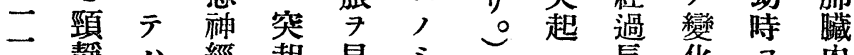

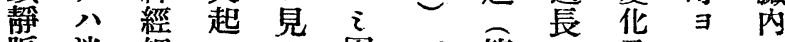
脈迷細, 岁固力節手及》,

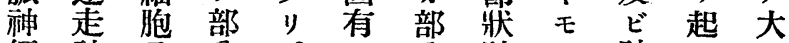
粨神及分。广分神, 神り子 節經 八, 其膨于 $千=$ 節亮細長有

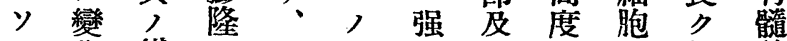

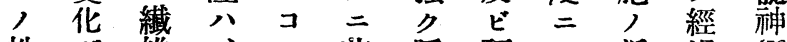
性分維, , 非腫頸言近過經

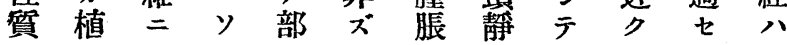

篗

音堪虽 , 告正痛 名, 變

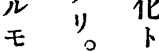
飔 点㫿公 思少 几有 。籍, 何性 7 卜就認 子經 $v$, 得 バ 䉇 他㩆。 人殊 新 $i=$ 鮮 二 神 $ナ$ 極 經 几x 細

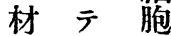
料 輕 内 及度 原

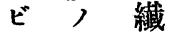

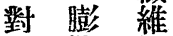
照隆 絧 例 7 , 証蓄 於为磨 


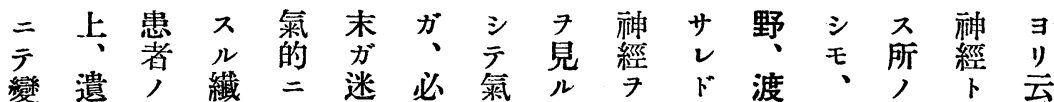

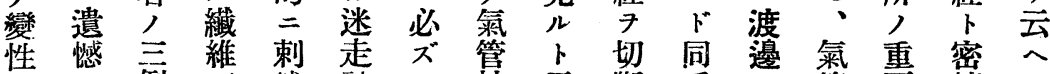

七ナ例吕戟神 シ 枝云斷昏了管要接バ 氣

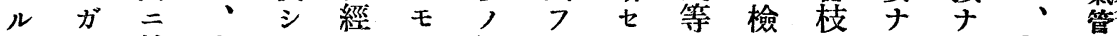

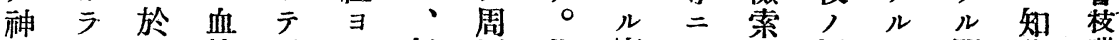

經、テ管、、リ氣圍此實 $、$ 周 反關覺喘

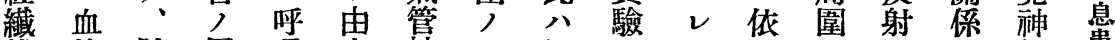

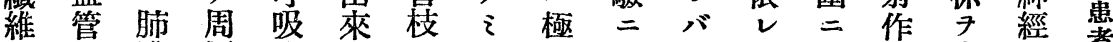

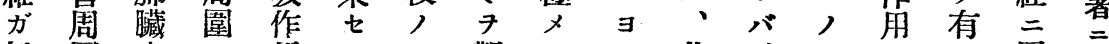

氣圄內 等

管ノ モ 枝神走存一, 局七注、神静出關且儿几 成經行在、定ナ限り。意迷經脈サ係此モ 植 周梠 ス

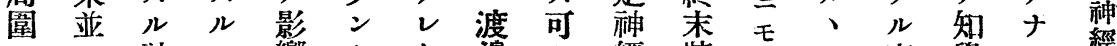

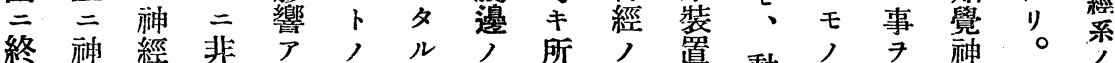
止 經 束 ザル 瀧 モ、見變 方動二推經 故組 七瀻中ル事野, 肺二性、物非定心二織

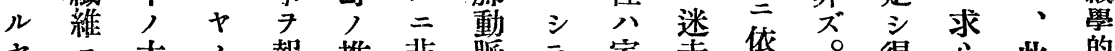
、三大了報推韭脈示家走依。得心此的

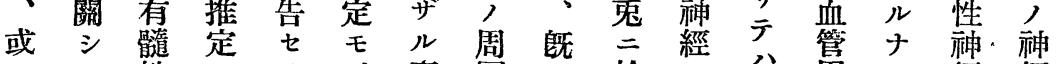

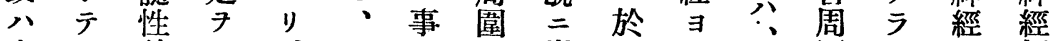

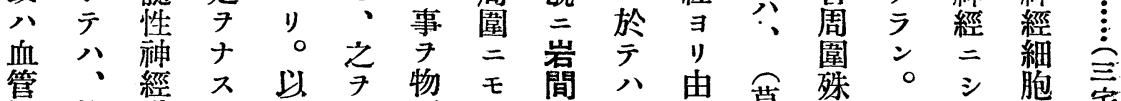

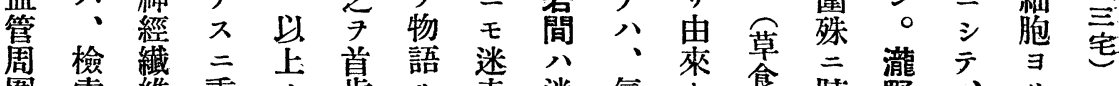
圍索維重, 啃ル走迷氣七食肺野、、り

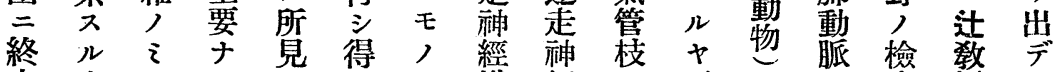
此事二ルハルナ瀻經了否知〉索授々

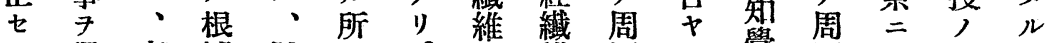
ル得病據肺ナ。方維圍八覺圍因學袖

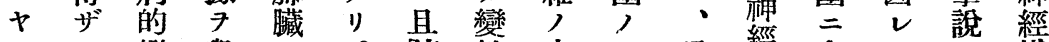

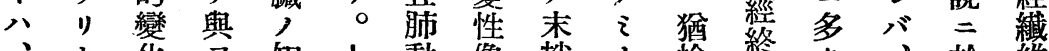
、キ化 フ 知小動像梢ナ檢絑 ク於維

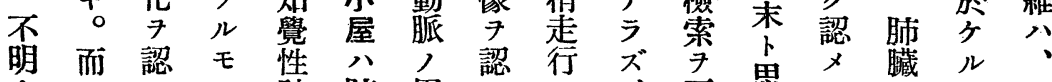

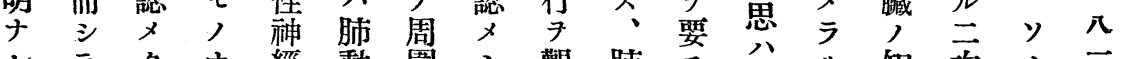

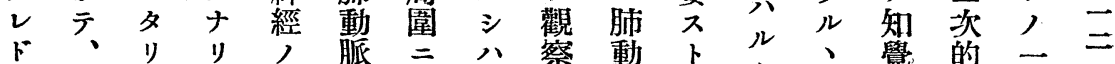

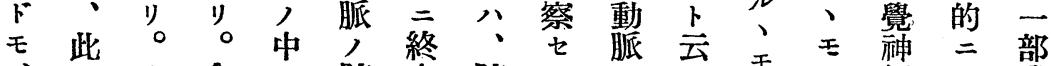

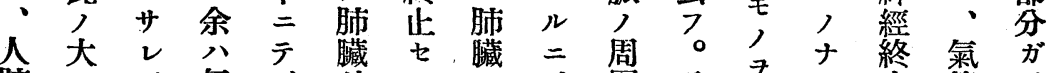

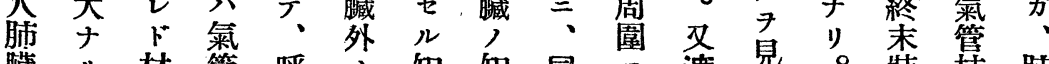
躟ル材管呼, 知知同二渡息。裝枝肺 二神料枝吸部覺覺氏 モ 邊 出最置攣 贜

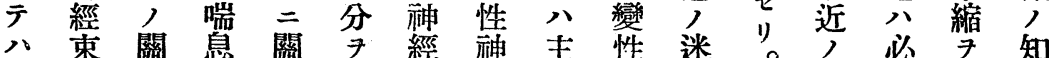

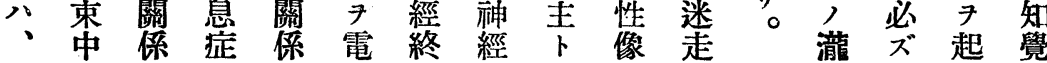




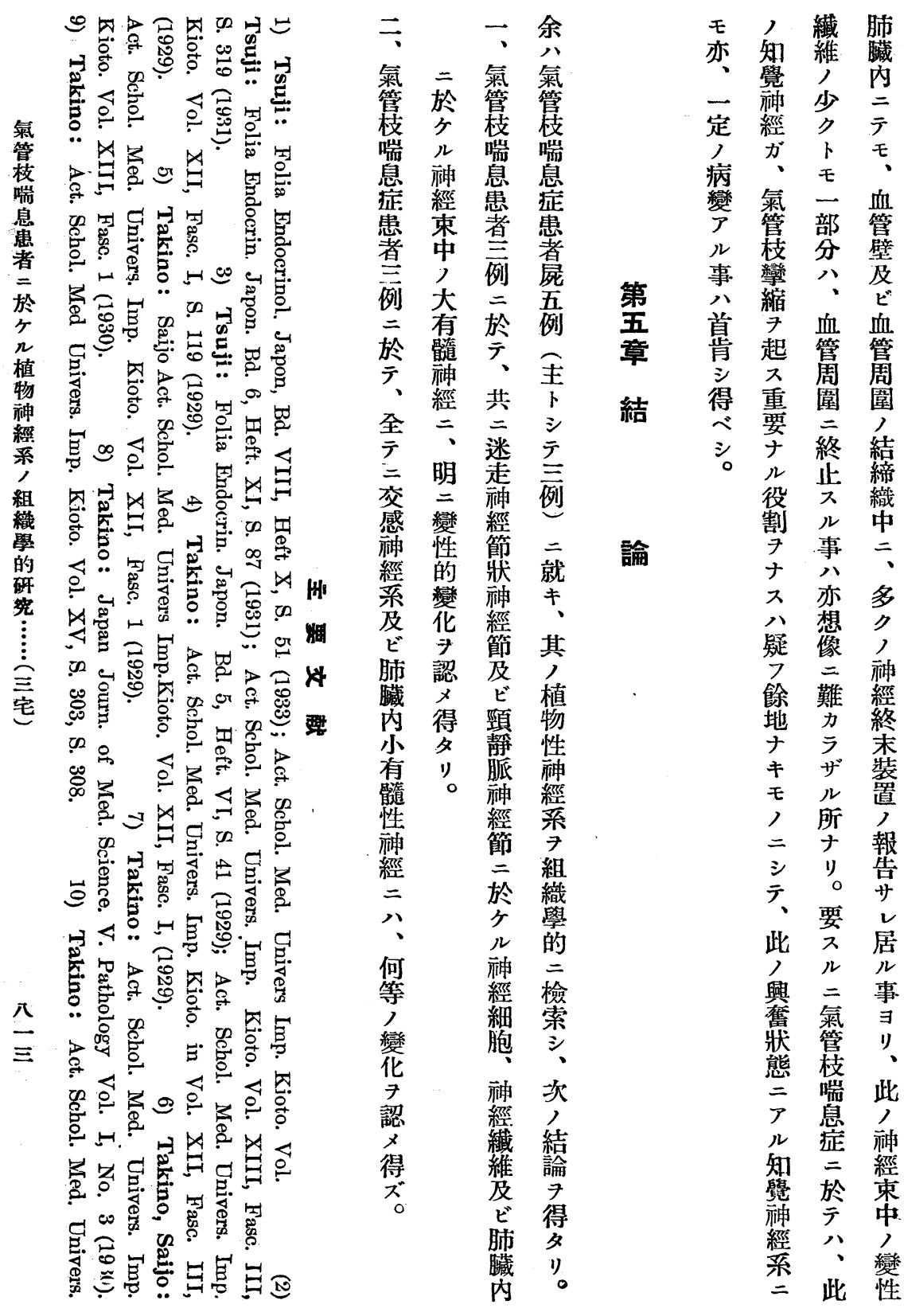




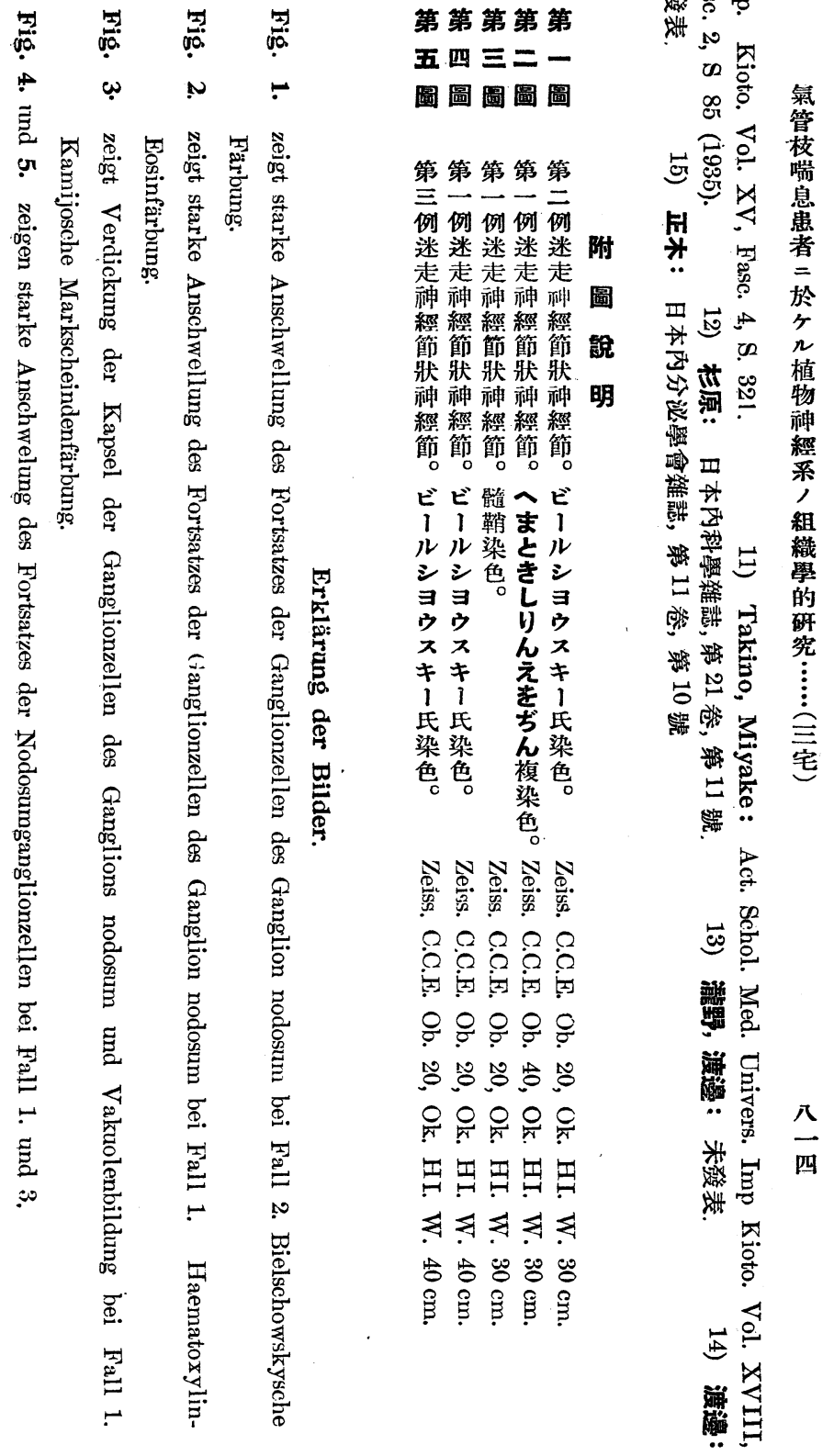




\section{第一圖}

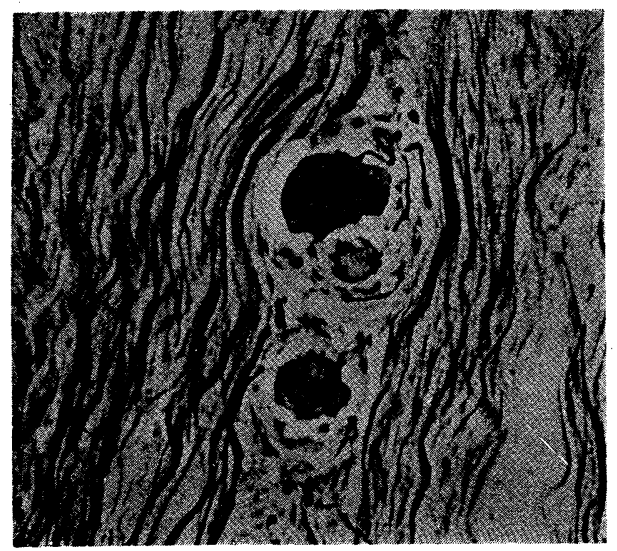

第二圖

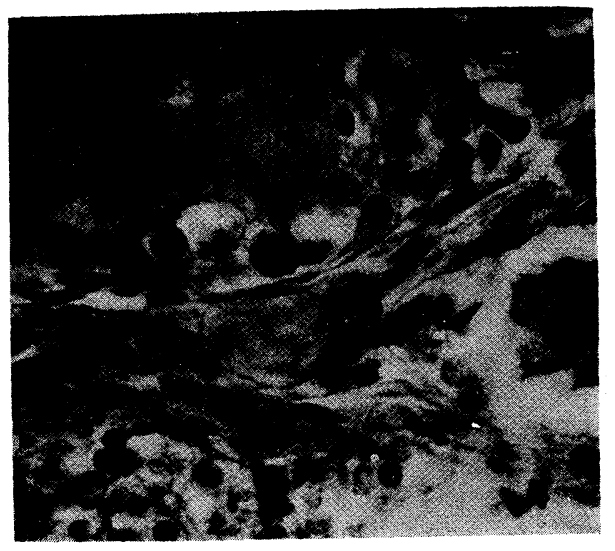

第三圖

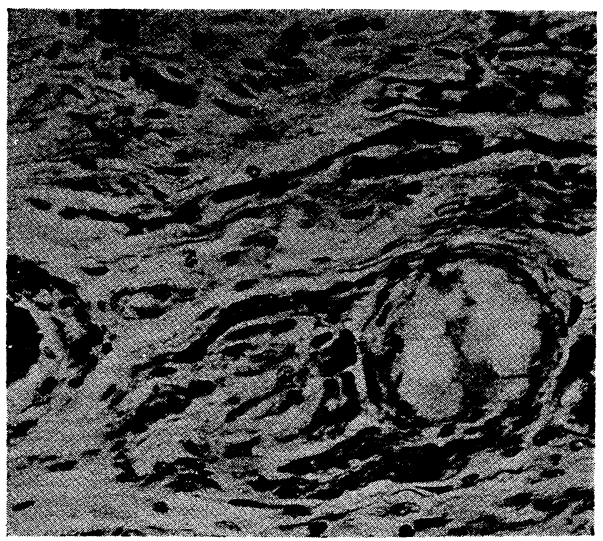

第四圆

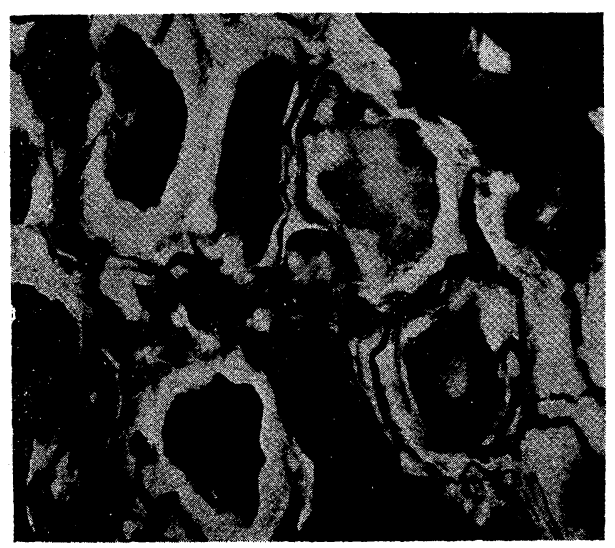

第五圖

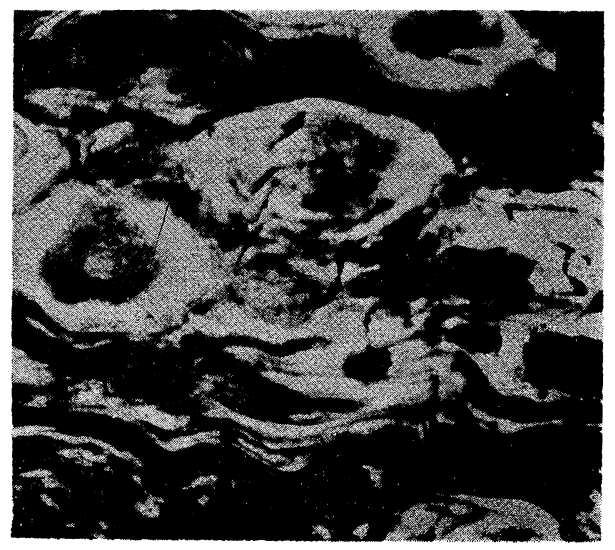


.4) Die A-Avitaminösen thymuslosen 'Tiere lebten weniger langals die Kontrolltiere. Auch kam es bei ihnen schneller zur Xerophthalmie.

5) Aus den obigen Resultaten möchte der Verfasser schliessen, dass die mit einer geeigneten Menge Thymussubstanz gefütterten Tiere vor A-Vitaminmangel bewahrt bleiben, während bei den Tieren mit exstirpierter Thymusdrüse das Auftreten des A-Vitaminmangels: beschleunigt wird.

(Autoreferat)

\title{
Histologische Untersuchung des vegetativen Nervensystems beim Asthma bronchiale.
}

\author{
Von \\ Dr. S. Miyake.
}

(Aus der I. Med. Klinik der Kaiserl. Univers. zu Kyoto in Japan. Direktor: Prof. Dr. K. Tsuji.)

Der Verfasser untersuchte histologisch das vegetative Nervensystem, besonders auf bei den Seiten, das Ganglion jugulare, Ganglion nodosum, Ganglion cervicale superius, Ganglion medius und Ganglion inferius sowie die Nerven der Lunge bei 5 Asthmatikern.

Die Resultate waren wie folgt:

1. Die Ganglionzellen des Ganglion jugulare sowie des Ganglion nodosum zeigen bestimmte Veränderungen wie Aufblähung, Zerfall der Nisslschen Substanzen in feinste Stäbchen oder in grobere Körner, Tigrolyse, Verlagerung sowie Anschwellung der Kerne und Anschwellung der Fortsatze. Was die Veranderungen der intracellularen Fibrillennetze anbetrifft so war hier schlechte, dagegen abnorm starke Imprägnation, Verklebung, Fragmentierung nud partieles Verschwinden bemerkbar.

2) Auch die dick markhaltigen Nervenfarern in der Lunge waren stellenweise degenerativ verändert in Form von Auftreibung usw.

3) Die Ganglionzellen des Ganglion cervicale und die dünnmarkhaltigen Nervenfasern in der Lunge liessen keine pathologischen Veränderungen erkennen.

(Autoreferat) 